\title{
First record of Histiotus velatus I. Geoffroy St.-Hilaire, 1824 (Chiroptera, Vespertilionidae) in Salta province, Argentina
}

\author{
Sofía T. Aramayo ${ }^{1}$, M. Mónica Díaz ${ }^{1,2,3,4}$, María Daniela Miotti ${ }^{1,3}$, E. J. Derlindati ${ }^{5}$ \\ 1 PCMA (Programa de Conservación de los Murciélagos de Argentina), Argentina. 2 Consejo Nacional de Investigaciones Científicas y Técnicas \\ (CONICET). 3 PIDBA (Programa de Investigaciones de Biodiversidad Argentina, Facultad de Ciencias Naturales e Instituto Miguel Lillo, \\ Universidad Nacional de Tucumán. Miguel Lillo 205, 4000. Tucumán, Argentina. 4 Fundación Miguel Lillo. Miguel Lillo 251, 4000. Tucumán, \\ Argentina. 5 LEAC (Laboratorio de Ecología Aplicada a la Conservación), Cátedra de Biología de los Cordados, Ecología de comunidades en \\ ambientes Áridos y semiáridos y Consejo de Investigaciones de la Universidad Nacional de Salta, Avenida Bolivia 5150, 4400. Salta, Argentina. \\ Corresponding author: M. Mónica Díaz, mmonicadiaz@yahoo.com.ar
}

\begin{abstract}
We present here the first record of Histiotus velatus I. Geoffroy St.-Hilaire, 1824 for the province of Salta, Argentina. Until now, in Argentina, this species was only known from Jujuy, Corrientes, and Misiones provinces. Our record adds a fourth province to the distribution of this species in the country and the second record for the Northwestern Argentina, rising to 39 the number of bat species in Salta. We captured three adult males with mist-nets placed in Parque Nacional El Rey. This site represents one of the last largest continuous blocks of protected forests, within a region affected by the greatest anthropic transformation (e.g. agricultural development, cattle grazing) of northwestern Argentina.
\end{abstract}

\section{Keywords}

Distribution, Histiotus, northwestern Argentina, Yungas.

Academic editor: Faisal Ali Anwarali Khan | Received 15 August 2019 | Accepted 6 October 2019 | Published 1 November 2019

Citation: Aramayo ST, Díaz MM, Miotti MD, Derlindati EJ (2019) First record of Histiotus velatus I. Geoffroy St.-Hilaire, 1824 (Chiroptera, Vespertilionidae) in Salta province, Argentina. Check List 15 (6): 973-978. https://doi.org/10.15560/15.6.973

\section{Introduction}

Salta province includes a region of great geographical and biological complexity, and supports a wide array of habitats, from arid, high elevation, puna desert, and montane grasslands in the west, to montane rainforest in the central portions, to semiarid thorn scrub in the east, and arid Monte Desert in the south; it also has a diverse mix of ecotonal habitats (Ojeda and Mares 1989, Díaz et al. 2000). However, its natural vegetation has been so strongly affected that, at present, it is highly fragmented due mainly to agricultural development (Boletta et al. 2006; Hoyos et al. 2012). The mammals of the province were extensively studied (Mares et al. 1981, 1989; Ojeda and Mares 1989; Díaz et al. 2000) reflecting that it was the second most diverse province with respect to its bat fauna, with a total of 38 species (Barquez et al. 1999, 2011; Barquez and Díaz 2009).

Histiotus Gervais, 1856 is an endemic genus from South America containing eight species: H. alienus (Thomas, 1916); H. diaphanopterus Feijó et al., 2015; $H$. humboldti Handley, 1996; H. laephotis Thomas, 1916; H. macrotus (Poeppig, 1835); H. magellanicus (Philippi, 1866); H. montanus (Philippi and Landbeck, 1861); and H. velatus (Geoffroy St.-Hilaire, 1824) (Simmons 2005; Barquez 2006; Feijó et al. 2015; Díaz et al. 2016, 2019). It is important to mention that Handley and Gardner (2008) considered to H. alienus, H. laephotis, and $H$. 
magellanicus as subspecies of $H$. montanus. Five species are distributed in Argentina (Barquez et al. 1999, Barquez and Díaz 2009, Díaz et al. 2016), and four of them, Histiotus laephotis, $H$. macrotus, $H$. montanus, and $H$. velatus, are present in the northwest (Barquez 2006; Barquez and Díaz 2009). Until now, in the northwestern Argentina, Histiotus velatus was only known from Jujuy province. Here we report $H$. velatus for the province of Salta, Argentina, representing the first record of the species for the province, the second known locality for northwestern Argentina and the fourth argentine province for its distribution.

This species, in Argentina (Díaz 2012) and throughout its distribution, is listed as Data Deficient by the International Union for Conservation of Nature and Natural Resources (González and Barquez 2016), “....in view of continuing problems with its taxonomy as well as absence of recent information on its extent of occurrence, status and ecological requirements" (González and Barquez 2016: 1).

\section{Methods}

The survey was carried on between November 2017 and March 2018 in Parque Nacional El Rey, as part of an ecological study which included the use of mist nets randomly in different microhabitats inside the Park. The collection site was an open area of grasses with artificial lights close to the park buildings (Fig. 1). The specimen was originally preserved in alcohol $70 \%$, and posteriorly prepared as skin, skull and skeleton, and deposited at the Colección Mamíferos Lillo (CML), Universidad Nacional de Tucumán, Tucumán, Argentina. Other two individuals of the species were captured, but released.

The locality of collection belongs to the Yungas ecoregion, characterized by montane subtropical deciduous forests (Brown et al. 2009; Martínez and Prado 2014). Study site belongs to a protected area, Parque Nacional El Rey, that was surrounded with land where

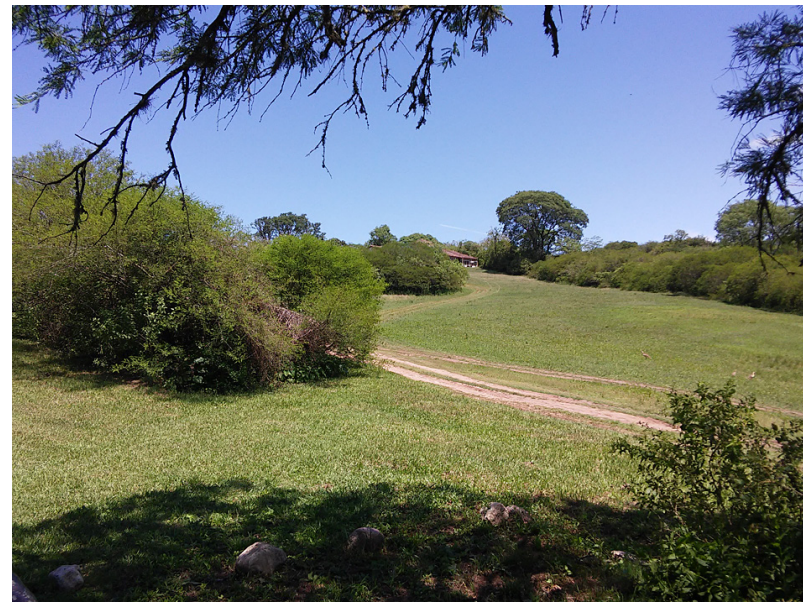

Figure 1. Collection site of the specimen of Histiotus velatus, an open area of grasses in Parque Nacional El Rey, Salta, Argentina. deforestation has recently been intensified by the rapid expansion of soybean crops and cattle grazing (Zak et al. 2004; Hoyos et al. 2012; Prado et al. 2012, Hansen et al. 2013). The collection area is a prairie of natural vegetation, surrounded second growth forest and park buildings.

In the Yungas vegetation there are tall trees such a Cedrela angustifolia Sessé and Moc. ex DC, Enterolobium contortisiliquum (Vell.) Morong, Anadenanthera colubrina (Vell.) Brenan, Cinnamomum porphyrium (Griseb.) Kosterm., and Myrcianthes pungens (O.Berg) D. Legrand (mato); smaller trees, including Allophyllus edulis (A. St.-Hil., A. Juss. and Cambess.) Hieron. ex Niederl., and Celtis brasiliensis (Gardner) Planch. (tala); and the shrubs Urera baccifera (L.) Gaudich. Piper tucumanum C. DC. and Solanum spp. (Cabrera 1976).

The identification of the species was made using identification keys published by Barquez et al. (1999) and Díaz et al. (2016) as well as by comparison with specimens of other species of the genus deposited at the CML (see Appendix).

\section{Results}

New record. Argentina: Salta province, Anta Department: Parque Nacional El Rey, a 200 m de la intendencia $\left(24^{\circ} 43^{\prime} 05^{\prime \prime} \mathrm{S}, 064^{\circ} 38^{\prime} 42^{\prime \prime} \mathrm{W}, 926 \mathrm{~m}\right.$ a.s.l.) (Fig. 2), collected by Sofía Aramayo on January 23, 2018, wet season (summer in the southern hemisphere); an adult male (CML 13338). The released specimens were: two adult males captured on November 19, 2017 and on March 17, 2018.

Identification. In Salta there are also two other species of the genus Histiotus (Barquez and Díaz 2009), $H$. laephotis and H. macrotus, but the most distinguishing character of $H$. velatus is the pointed and triangular shaped ears, compared with the other two species that have rounded and oval shaped ears. The ears are connected by a ca $3 \mathrm{~mm}$ membrane in this species and in H. laephotis, which is lower in H. macrotus (2 $\mathrm{mm})$; but in $H$. laephotis the color of the ears is yellowish while in $H$. velatus and $H$. macrotus is dark brown (Fig. 2). In other species from Argentina, such as H. magellanicus and $H$. montanus the connecting band between the ears are either absent or small (Díaz et al. 2016).

Histiotus velatus is a medium size species; in the external measurements, the male examined is slightly smaller than the females collected in Jujuy province (Table 1). The dorsal coloration of the specimen examined is dark brown with almost unicolored hairs, and pale drab ventrally with bicolored hairs (Fig. 3 ); it is slightly darker than other specimens examined from Jujuy province (CML 7059, 11916); the wings and ears membranes are dark drab but paler than H. macrotus. The skull is similar to those of the other species of Histiotus, with a rostrum narrower than that of $H$. laephotis and H. macrotus, without sagittal crest and 


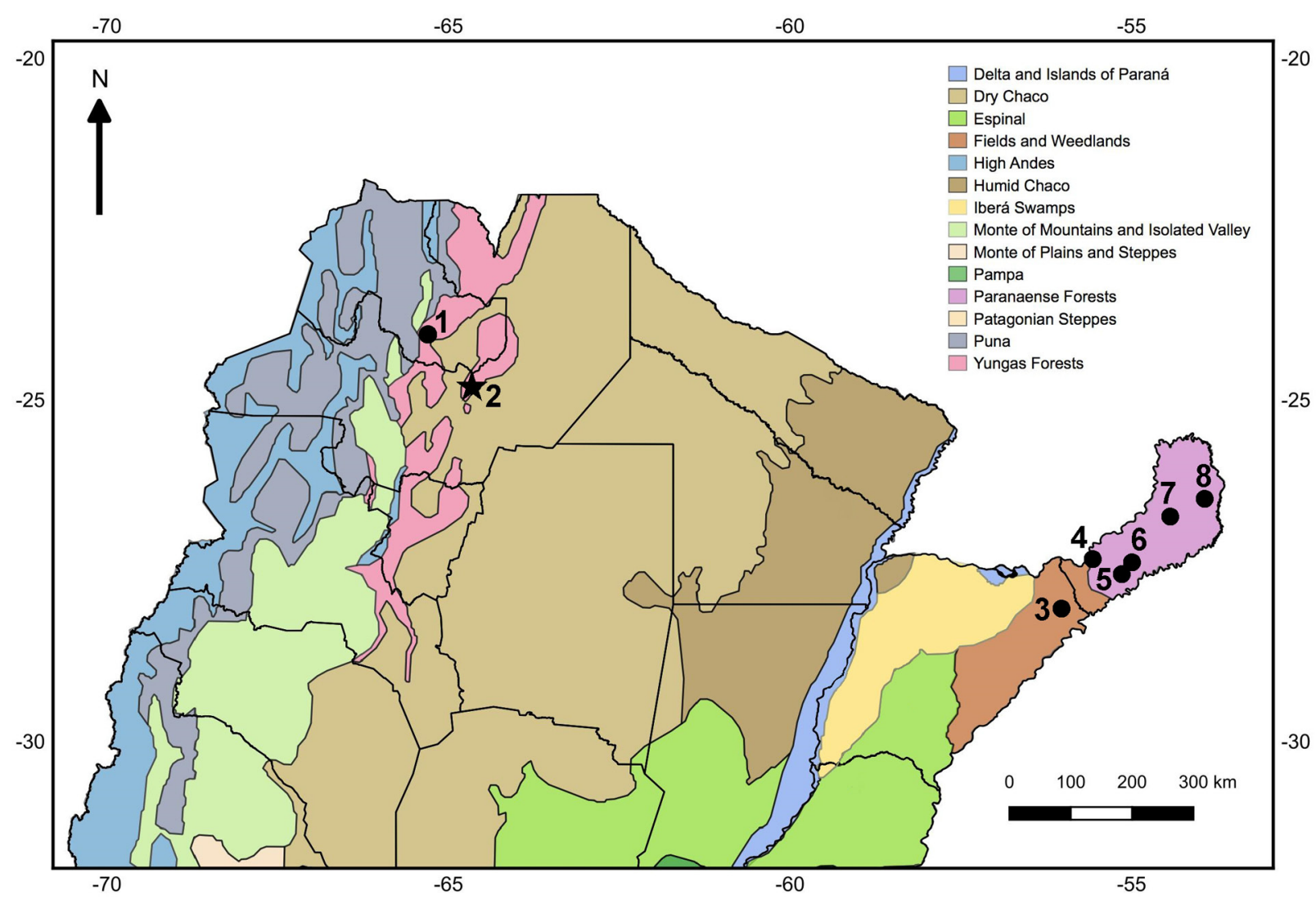

Figure 2. Distribution of Histiotus velatus in Argentina. Black dots indicate previous localities and the star shows the new one. $1=$ Río Las

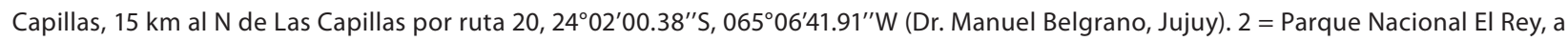

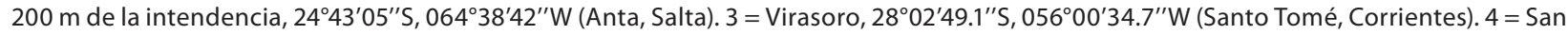

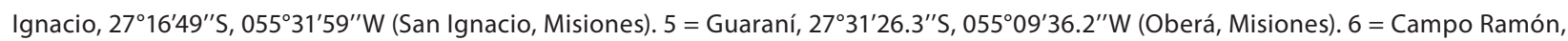
$27^{\circ} 27^{\prime} 22.6^{\prime \prime} \mathrm{S}, 055^{\circ} 01^{\prime} 20.8^{\prime \prime} \mathrm{W}$ (Oberá, Misiones). 7 = Río Victoria, 2657'51.7" S, 054²9'48.4"W (Guaraní, Misiones). 8 = Frontera Tobuna, $26^{\circ} 28^{\prime} 12.53^{\prime \prime} \mathrm{S}, 053^{\circ} 53^{\prime} 29.0^{\prime \prime} \mathrm{W}$ (San Pedro, Misiones). Ecoregions classified according to Burkart et al. (1999).

well-marked postorbital constriction, and the postorbital process of the jugal, in the zygomatic arches, welldeveloped (Fig. 4).

Table 1. External and cranial measurements in $\mathrm{mm}$ (following Barquez et al. 1999) of the specimen of Histiotus velatus from Salta (CML 13338) compared with other two specimens from Jujuy province (Argentina).

\begin{tabular}{lccc}
\hline Variables & CML & CML & CML \\
& $\mathbf{1 3 3 3 8}$ & $\mathbf{7 0 5 9}$ & $\mathbf{1 1 9 1 6}$ \\
\hline Sex & Male & Female & Female \\
Total length & 95 & 125 & 120 \\
Tail length & 43 & 59 & 56 \\
Hindfoot length & 10 & 10.6 & 8 \\
Ear length & 31 & 33 & 35 \\
Weight & - & 11 & 12 \\
Forearm & 47.4 & 46.5 & 48 \\
Greatest length of skull & 19.0 & 18.9 & 18.6 \\
Condylobasal length & 18.6 & 18.1 & 18.2 \\
Postorbital constriction & 4.2 & 4.0 & 4.0 \\
Zygomatic breadth & 10.5 & 10.8 & 10.4 \\
Breadth of braincase & 8.2 & 8.1 & 7.9 \\
Mastoideal breadth & 9.4 & 9.5 & 9.2 \\
Width across C-C & 4.9 & 4.9 & 4.7 \\
Width across M2-M2 & 6.4 & 6.5 & 6.3 \\
Length of maxillary toothrow & 6.4 & 6.3 & 6.2 \\
Length of mandible & 12.8 & 13.3 & 12.8 \\
Length of mandible toothrow & 6.7 & 6.7 & 6.6 \\
\hline
\end{tabular}

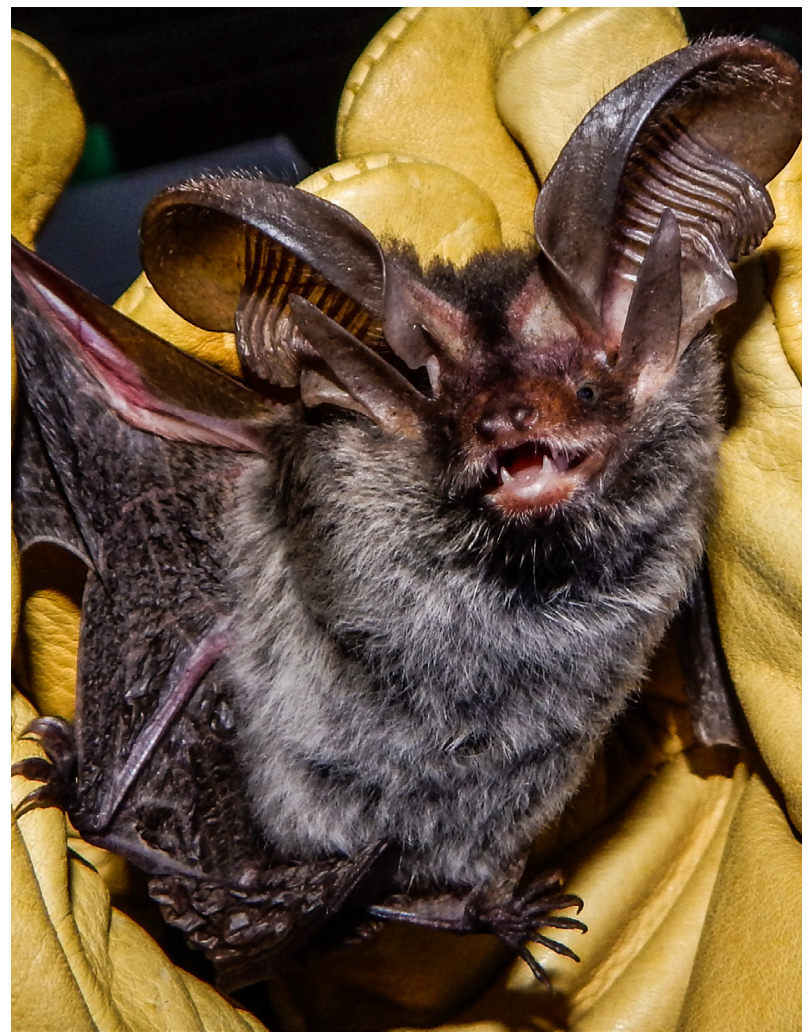

Figure 3. Living specimen of Histiotus velatus at the moment of capture in Parque Nacional El Rey, Salta, Argentina. 


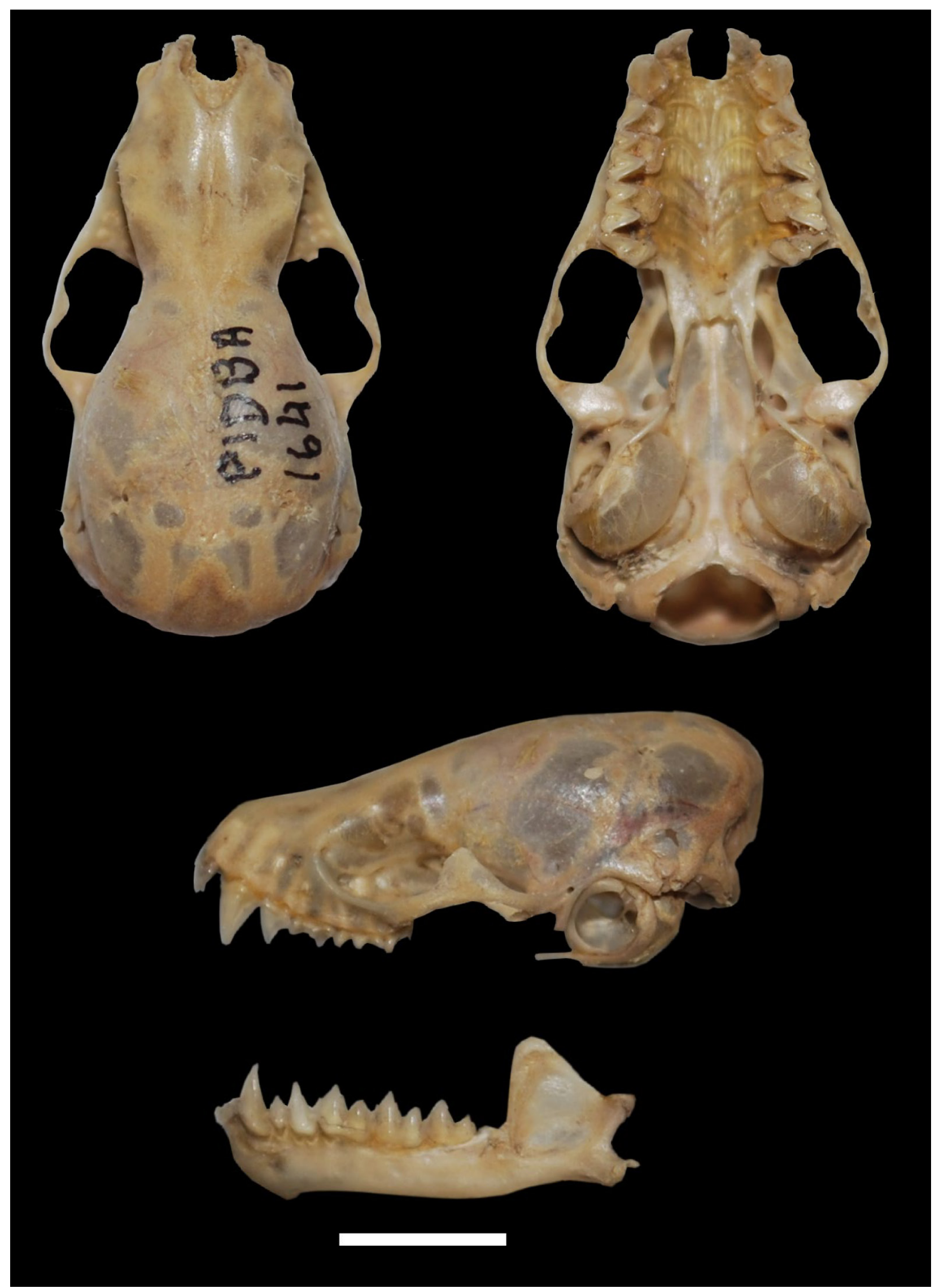

Figure 4. Dorsal, ventral, and lateral views of the skull and lateral view of the mandible of Histiotus velatus (CML 13338). 


\section{Discussion}

Histiotus velatus is distributed in Argentina, Bolivia, Brazil, Paraguay, Perú, and Uruguay (Díaz et al. 2016). In Argentina, this species is known from just a few localities in the northeast and northwest regions (Fig. 2). The new record of $H$. velatus from the province of Salta adds a new locality to Northwestern Argentina, because the only known previous record was from Jujuy province (Barquez and Díaz 2001, 2007; Barquez 2006; Gamboa Alurralde et al. 2016). The first records of this species for Argentina were obtained in 1970 in the province of Misiones, while the specimens from Jujuy (in the northwest) were obtained in 1997, almost 30 years later, and then recently in 2012, after continuous efforts for collecting bats, which reflects the scarcity and rarity of the species in the country. This species needs more studies to determine if the populations along its distributional range all belong to a unique entity (see also González and Barquez 2016).

On the other hand, it has to be mentioned that little is known about different aspects of its biology which, added to the fact that fragmentation and destruction of its habitat in Northwestern Argentina is within the highest rates of deforestation on a planetary scale (Hansen et al. 2013), should highlight the need of having more precise information about its distribution, conservation status, and ecology.

\section{Acknowledgements}

We thank Julieta Perez for taking the photos of the skull of the specimen.

\section{Authors' Contributions}

SA and ED participates in specimens' collection, MMD reviewed and identified the specimens at the collection Colección Mamíferos Lillo; SA, MMD, MDM and ED wrote the text.

\section{References}

Barquez RM (2006) Orden Chiroptera. In: Barquez RM, Díaz MM, Ojeda RA (Eds) Mamíferos de Argentina, sistemática y distribución. Sociedad Argentina para el estudio de los Mamíferos, Mendoza 56-86.

Barquez RM, Díaz MM (2001). Bats of the Argentine Yungas: a systematic and distributional analysis. Acta Zoológica Mexicana 82: 29-81.

Barquez RM, Díaz MM (2009) Los murciélagos de Argentina-clave de identificación. Publicación Especial No. 1. Programa de Conservación de los Murciélagos de Argentina), Editorial Magna Publicaciones, Tucumán, Argentina, 80 pp.

Barquez RM, Mares MA, Braun JK (1999) The bats of Argentina. Special Publications, Museum of Texas Tech University 42: 1-275.

Barquez RM, Sánchez MS, Sandoval ML (2011) Nuevos registros de murciélagos (Chiroptera) para el norte de Argentina. Mastozoología Neotropical 18: 11-24.

Boletta PE, Ravelo AC, Planchuelo AM, Grilli M (2006). Assessing deforestation in the Argentine Chaco. Forest Ecology and Man- agement 228 (1-3): 108-114. https://doi.org/10.1016/j.foreco.2006. 02.045

Brown AD, Blendinger P, Lomáscolo T, Bes PG, eds. (2009) Selva pedemontana de las Yungas. Historia natural, ecología y manejo de un ecosistema en peligro. Ediciones del Subtrópico, San Miguel de Tucumán, Argentina, 487 pp.

Burkart R, Bárbaro NO, Sánchez RO, Gómez DA (1999) Ecoregiones de la Argentina. Administración de Parque Nacionales, Buenos Aires, 43 pp.

Cabrera AL (1976) Regiones fitogeográficas Argentinas. ACME, Buenos Aires, $85 \mathrm{pp}$.

Díaz MM (2012) Orden Chiroptera. In: Ojeda RA, Chillo V, Diaz Isenrath GB (Eds) Libro rojo, mamíferos amenazados de la Argentina. Sociedad Argentina para el Estudio de los Mamíferos, Argentina, 67-80.

Díaz MM, Barquez RM (2007) The wild mammals of Jujuy province, Argentina: systematics and distribution. In: Kelt DA, Lessa EP, Salazar-Bravo JA, Patton JL (Eds) The quintessential naturalist: honoring the life and legacy of Oliver Pearson. University of California Publications in Zoology 134: 417-578.

Díaz MM, Ossa G, Barquez RM (2019) Histiotus magellanicus (Chiroptera: Vespertilionidae). Mammalian Species 51: 18-25. DOI??

Díaz MM, Braun JK, Mares MA, Barquez RM (2000) An update of the taxonomy, systematics, and distribution of the mammals of Salta province, Argentina. Occasional Papers, Oklahoma $\mathrm{Mu}$ seum of Natural History 10:1-52.

Díaz MM, Solari S, Aguirre LF, Aguiar L, Barquez RM (2016) Clave de identificación de los murciélagos de Sudamérica/Chave de indentificação dos morcegos da América do Sul. Publicación Especial PCMA Nro 2. Editorial Magna Publicaciones, Tucumán, $160 \mathrm{pp}$.

Feijó A, Rocha PA Da, Althoff SL (2015) New species of Histiotus (Chiroptera: Vespertilionidae) from northeastern Brazil. Zootaxa 4048 (3): 412-427. https://doi.org/10.11646/zootaxa.4048.3.4

Gamboa Alurralde S, López Berrizbeitia MF, Barquez RM, Díaz MM (2016) Diversity and Richness of Small Mammals at well conserved site of Las Yungas in Jujuy Province, Argentina. Mammalia 80 (3): 253-262.

Geoffroy St.-Hilaire I (1824) Sur les vespertilions du Brésil. Annales des Sciences Naturelles, Paris 3: 440-47.

Gervais, P. 1856. Deuxième Mémoire. Documents zoologiques pour servir à la monographie des chéiroptères sud-américains. In: P. Gervais (Ed.) Mammiféres. Vol. 1, In: de Castelnau F (Ed.). Animaux nouveaux ou rares recueillis pendant l'expédition dans les parties centrales de l'Amérique du Sud, de Rio de Janeiro a Lima, et de Lima au Para; exécutée par ordre du gouvernement Français pendant les années 1843 à 1847.... P. Bertrand, Paris, 28-88.

González EM, Barquez RM (2016) Histiotus velatus. The IUCN Red List of Threatened Species 2016: e.T10203A22098684. https://doi. org/10.2305/IUCN.UK.2016-2.RLTS.T10203A22098684.en. Accessed on: 2019-6-18.

Handley CO Jr (1996) New species of mammals from northern South America: bats of the genera Histiotus Gervais and Lasiurus Gray (Mammalia: Chiroptera: Vespertilionidae). Proceedings of the Biological Society of Washington 109: 1-9.

Handley CO Jr, Gardner AL (2008) Genus Histiotus P. Gervais, 1856. In: Gardner AL (Ed.) Mammals of South America. Volume 1, marsupials, xenarthrans, shrews, and bats. The University of Chicago Press, Chicago, 450-457.

Hansen MC, Potapov PV, Moore R, Hancher M, Turubanova SA, Tyukavina A, Thau D, Stehman SV, Goetz SJ, Loveland TR, Kommareddy A, Egorov A. Chini L, Justice CO, Townshend JR G (2013). High-resolution global maps of 21st-century forest cover change. Science 342:850-853. https://doi.org/10.1126/science.1244693

Hoyos LE, Cingolani AM, Zak MR, Vaieretti MV, Gorla DE, Cabido MR (2012). Deforestation and precipitation patterns in the arid Chaco forests of central Argentina. Applied Vegetation Science 16 (2): 260-271. https://doi.org/10.1111/j.1654-109X.2012.01218.x 
Mares MA, Ojeda RA, Barquez RM (1989). Guide to the mammals of Salta province, Argentina. University of Oklahoma Press, Norman, 303 pp.

Mares MA, Ojeda RA, Kosco MP (1981). Observations on the distribution and ecology of the mammals of Salta province, Argentina. Annals of the Carnegie Museum 50:151-206.

Martínez OG, Prado DE (2014). Phytogeographical distribution of ferns and lycophytes in the Lerma valley (Salta-Argentina). Chloris Chilensis 16 (2): 1-19.

Ojeda RA, Mares MA (1989) A biogeographic analysis of the mammals of Salta province, Argentina. Patterns of species assemblage in the Neotropics. Special Publications of the Museum 27: 1-66.

Philippi RA (1866) Ueber ein paar neue Chilenische Säugethiere. Archiv für Naturgeschichte 32: 113-117.

Philippi RA, Landbeck L (1861). Neue Wirbelthiere von Chile. Archiv für Naturgeschichte 27: 289-301.

\section{Appendix}

Specimens examined. For each specimen, the localities are listed alphabetically by province and department, then by specific site and coordinates between parentheses, numbers of specimens, collection acronym and number. The acronym used in the text is CML (Colección Mamíferos Lillo), Tucumán, Argentina.

Histiotus laephotis (3). JUJUY. Dr. Manuel Bel-

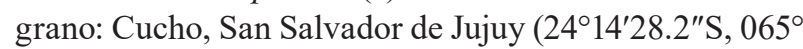
14'59.3"W; 1210 m a.s.1.), 1 (CML 1682); Ledesma: Parque Nacional Calilegua, Arroyo Sauzalito $\left(23^{\circ} 38^{\prime} 33^{\prime \prime} \mathrm{S}, 064^{\circ}\right.$ 36'6.71”W; 474 m a.s.1.), 1 (CML 2923); San Pedro: Río Lavayén, app. $1 \mathrm{~km}$ al $\mathrm{N}$ de Santa Rita $\left(24^{\circ} 27^{\prime} 41.6^{\prime \prime} \mathrm{S}\right.$, 064 50'45.28"W; 536 m a.s.1.), 1 (CML 7058).

Histiotus macrotus (10). JUJUY. Humahuaca: $8 \mathrm{~km}$ al $\mathrm{S}$ de Tres Cruces al lado de ruta $9\left(22^{\circ} 56^{\prime} 18.8^{\prime \prime} \mathrm{S}, 065^{\circ}\right.$
Poeppig EL (1835) Reise in Chile, Peru, und auf dem Amazonenströme während de Jahre 1827-1832. Band 1. F. Fleischer, Leipzig, xii +466 pp.

Prado W, Waller T, Albareda D, Cabrera MR, Etchepare E, Giraudo AR, González Carman V, Prosdocimi L, Richard E (2012) Categorización del estado de conservación de las tortugas de la República Argentina. Cuadernos de Herpetología 26 (supplement 1): 375-388.

Simmons NB (2005) Order Chiroptera. In: Wilson DE, Reeder DM (Eds) Mammal species of the world, 3rd edition. The Johns Hopkins Press, Baltimore, 312-529.

Thomas O (1916) Notes on bats of the genus Histiotus. The Annals and Magazine of Natural History (Series 7) 17: 272-276.

Zak MR, Cabido M, Hodgson JG (2004). Do subtropical seasonal forests in the Gran Chaco, Argentina, have a future? Biological Conservation 120 (4): 589-598. https://doi.org/10.1016/j.bio con.2004.03.034

31'16.59"W; 3619 m a.s.1.), 3 (CML 5408, 5409, 6066); Yavi: $6.8 . \mathrm{km}$ al SE de Suripujio sobre ruta provincial № 5 (22 $2^{\circ} 13^{\prime} 27^{\prime \prime} \mathrm{S}, 065^{\circ} 16^{\prime} 12.2^{\prime \prime} \mathrm{W}$; $3991 \mathrm{~m}$ a.s.l.), 1 (CML 7891). SALTA. Molinos: Laguna El Brealito $\left(25^{\circ} 17^{\prime}\right.$ 22.5"S, $066^{\circ} 22^{\prime} 04.8^{\prime \prime} \mathrm{W} ; 2585 \mathrm{~m}$ a.s.1.), 4 (CML 7893, 1895, 7896, 7897); San Carlos: $20 \mathrm{~km}$ al NW de Cafayate, camino a El Barreal $\left(25^{\circ} 57^{\prime} 56.1^{\prime \prime} \mathrm{S}, 065^{\circ} 55^{\prime} 33.85^{\prime \prime} \mathrm{W}\right.$; 1613 m a.s.1.), 2 (CML 5406, 5407).

Histiotus velatus (3). JUJUY. Dr. Manuel Belgrano: Río Las Capillas, $15 \mathrm{~km}$ al $\mathrm{N}$ de Las Capillas por ruta 20 ( $24^{\circ} 02^{\prime} 00.38^{\prime \prime} \mathrm{S}, 065^{\circ} 06^{\prime} 41.91^{\prime \prime} \mathrm{W} ; 998 \mathrm{~m}$ a.s.1.), 2 (CML 7059, 11916); SALTA. Anta: Parque Nacional El Rey, a $200 \mathrm{~m}$ de la intendencia $\left(24^{\circ} 43^{\prime} 05^{\prime \prime} \mathrm{S}, 064^{\circ} 38^{\prime} 42^{\prime \prime} \mathrm{W} ; 926\right.$ $\mathrm{m}$ a.s.1.), 1 (CML 13338). 